\title{
Alternative approaches of addiction and dominant scientific perspectives
}

Sotiris Lainas

From $1^{\text {st }}$ International Congress on Neurobiology and Clinical Psychopharmacology and European

Psychiatric Association Conference on Treatment Guidance

Thessaloniki, Greece. 19-22 November 2009

The initiatives of the directly involved citizens like self help groups or organizations, throughout the years, have contributed decisively to the interpretation of the phenomenon of addiction and to the production of successful intervention paradigms. The dynamics of these approaches, their influence on the creation of successful alternative professional approaches and to behavioral sciences in general are discussed in this presentation. Additionally the influence the mainstream nosological approaches have on these alternative approaches nowadays are presented, along with the emerging danger of abolishment of their innovative characteristics.

Published: 22 April 2010

doi:10.1186/1744-859X-9-S1-S17

Cite this article as: Lainas: Alternative approaches of addiction and

dominant scientific perspectives. Annals of General Psychiatry 2010

9(Suppl 1):S17.
Psychologist, Coordinator of Self Help Promotion Program, Aristotle University of Thessaloniki, Greece

(๑) 2009 Lainas; licensee BioMed Central Ltd.
Submit your next manuscript to BioMed Central and take full advantage of:

- Convenient online submission

- Thorough peer review

- No space constraints or color figure charges

- Immediate publication on acceptance

- Inclusion in PubMed, CAS, Scopus and Google Scholar

- Research which is freely available for redistribution

Submit your manuscript at www.biomedcentral.com/submit 